\title{
Study on Molecular Structure of High Purity Natural Rubber Bei-long ZHANG ${ }^{\text {a, }}$, Hong-hai HUANG, Li DING, Yong-zhou WANG, Ping-yue WANG and Yue LIANG
}

Agricultural Product Processing Research Institute, Chinese Academy of Tropical Agricultural Sciences, P. O. Box 318, Zhanjiang, 524001, Guangdong, P.R. China

agdzjlong2013@163.com

${ }^{*}$ Corresponding author

Keywords: Natural rubber, High purity natural rubber, Non-rubber substances, Structure.

\begin{abstract}
Pyrolysis production and structure of molecule of high purity natural rubber (NR) were studied. Results show that there is no stretching vibration absorption peak of $\mathrm{N}-\mathrm{H}$ group on $3280 \mathrm{~cm}^{-1}$ and vibration compound peak of $\mathrm{C}-\mathrm{N}$ group and $\mathrm{N}-\mathrm{H}$ group in amide group on $1540 \mathrm{~cm}^{-1}$ in high purity NR comparing to NR. Pyrolysis productions of high purity NR are less than that of NR. Main pyrolysis products of high purity NR are Limonene, 1, 3-Pentadiene and 4-ethenyl-1, 4-dimethylCyclohexene, which is $58.98 \%$ of mass fraction of total pyrolysis productions.
\end{abstract}

\section{Introduction}

$\mathrm{NR}$ is a polymer made by coagulating and drying NR that is from Hevea brasiliensis, so it is a bio-synthetic natural high polymer material. As the need of growth physiological while Hevea brasiliensis are growing, a lot of substances are participators in the metabolic processes. According to analysis of Altman [1], besides rubber hydrocarbon and liquid, natural latex from Hevea brasiliensis contains nine types of non-rubber substances, including inorganic elements, protein, amino acids, sugars, organic acids, lipid, vitamin, nucleic acid and alkaloid. Non-rubber substances are closely relative to property of NR, so the relation between property and non-rubber substances has been widely studied. Gregg [2] et al. found in 1973 that non-rubber substances in white crepe have significant effect on property of rubber, particularly on scorch, heat building and tear strength. A.B.Othman [3] et al. discovered in 1996 that some amino acids can increase elastic modulus and reduce relaxation rate of vulcanizate. S.Tuampoemsab[4] et al. confirmed in 2007 the effect of protein and lipid on thermal aging behavior of purified NR. Kanjanee Nawamawat [5] et al. also confirmed in 2010 the significance effect of protein on property of NR during storage. Zhao qin-xiu[6] et al. in 1981 studied extraction and separation of phospholipid in NR latex and the effect of phospholipid on property of NR. M.Morimoto [7] found in 1985 that tocotrienols play an important role in anti-thermal aging of NR. The structure is closely relative to property of NR, however, the change of molecular structure after non-rubber substances in NR are removed has not been known. Composition and structure of polymer can be identified through the use of pyrolysis gas chromatography / mass spectrometry $[8,9,10]$. The pyrolytic products of NR are contributed to understanding of macromolecular structure of NR. In our work, high purity NR extracted most of non-rubber substances are analyzed by pyrolysis gas chromatography / mass spectrometry, and relationship between pyrolytic products and property of NR is studied. 


\section{Experiment}

\section{Materials}

Fresh NR latex was provided by Tuanjie Farm in Guangdong province, P.R. of China. Formic acid and sodium lauryl sulphate were of chemical grade. Others were Industrial grade.

\section{Preparation of NR sample}

\section{Preparation of High Purity NR}

Sodium lauryl sulphate was added into fresh NR latex, and was stirred fully. The level of sodium lauryl sulphate was $1.0 \%$ of weight of fresh NR latex and was made into sodium lauryl sulphate solution of 5-10\% with clean water before added into fresh NR latex. Alkaline protease was added and was stirred fully. The level of alkaline protease was $0.1 \%$ of weight of fresh NR latex and dissolve with water before added. After stand at room temperature for 24 hours, fresh NR latex containing sodium lauryl sulphate and alkaline protease was centrifuged by Type 410 centrifuge at rotate speed of $7000 \mathrm{r} / \mathrm{min}$. Then the concentrated NR latex was diluted to $25 \%$ with water and stand for 24 hours. The latex was dealt 3-4 times repeatedly according to above procedure to remove non-rubber substances such as protein, amino acids, lipid and so on. Finally the concentrated NR latex was diluted to $25 \%$ with water, and was coagulated with absolute ethyl alcohol that is 1-2 times weight of the latex. The coagulum was creped and granulated. The granule was soaked in clean water for 24 hours to remove water-soluble non-rubber substances. The granule was drained, then extracted with absolute ethyl alcohol for 24 hours to remove alcohol-soluble non-rubber substances. Finally the granule was dried in vacuum drying oven at $60^{\circ} \mathrm{C}$ for 36 hours

\section{Preparation of Control Sample}

Fresh NR latex containing $0.04 \%$ ammonia was coagulated with formic acid. The level of formic acid was $0.4 \%$ of weight of dry rubber in fresh NR latex, and the formic acid was diluted to $5 \%$ before adding into fresh NR latex. ( the other calculation should be make for the formic acid needed to neutralize the ammonia in fresh NR latex.) The coagulum was take out 18 hours after formic acid solution was put into fresh NR latex, then was creped, size-reduced and dried in an oven at $115^{\circ} \mathrm{C}$ for 5 hours.

\section{Test Method}

Infrared spectrometry was carried by PERKIN ELMER Spectrum GX Type Fourier transform infrared spectrometer, and resolution was $4 \mathrm{~cm}^{-1}$.

Pyrolysis of sample was carried out with use of (Agilent) PY-2020id/7890A GC/5975c MSD pyrolysis chromatography-mass spectrometry. The pyrolysis system consisted of UA-5 (5\%diphenyl) super alloy capillary chromatographic column $(30 \mathrm{~m} \times 0.25 \mathrm{~mm}$ i.d. $\times 0.25 \mu \mathrm{m})$. Pyrolysis temperature was $550^{\circ} \mathrm{C}$, carrier gas was helium and carrier gas rate was $50 \mathrm{~mL} / \mathrm{min}$. Sample $(100 \pm 10 \mu \mathrm{g})$ was put in platinum boat and then the platinum boat was put in pyrolyzer. Single-Shot Anacracker lysis of sample was conduct by PY-2020id vertical tube furnace cracker. The sample was pyrolyzed in an inert atmosphere at $550^{\circ} \mathrm{C}$ (which maintains for $0.5 \mathrm{~min}$.) and then the pyrolysis products were put in gas chromatography system.

UA-5 (5\% diphenyl) super alloy capillary chromatographic column $(30 \mathrm{~m} \times 0.25 \mathrm{~mm}$ 
i.d. $\times 0.25 \mu \mathrm{m}$ ) was used, and stationary phase material was a weakly polar polymethylphenyl silicone (5\%diphenyl).Temperature of injection port of separation column was $320^{\circ} \mathrm{C}$. Course of programmed temperature was: initial temperature $50^{\circ} \mathrm{C}$ maintaining $1 \mathrm{~min}$., and then temperature increasing to $320^{\circ} \mathrm{C}$ in a rate of $20^{\circ} \mathrm{C} / \mathrm{min}$., and maintaining $10 \mathrm{~min}$. Carrier gas was high purity helium. The carrier gas flow rate was $1.0 \mathrm{~mL} / \mathrm{min}$. Sample split ratio was $50: 1$. The total run time was $13.5 \mathrm{~min}$.

The temperature of GC/MS Interface was $300^{\circ} \mathrm{C}$.Ionization method was EI. Ionizing voltage was $70 \mathrm{eV}$. The temperatures of ion source and quadrupole rods were $230^{\circ} \mathrm{C}$ and $150^{\circ} \mathrm{C}$, respectively. Scan rate was $1 \mathrm{Scan} / \mathrm{Sec}$. The range of scan mass number was 35 500 amu. NIST08.L Mass spectrometry library was used to retrieve Ms spectra data.

Py-GC/MS and computer combination instrument were used to separate fragment ions (volatile component after sample pyrolysis) in chromatographic column and then to mass spectrum qualitative. NIST mass spectrometry library was used for retrieve analysis. Relative mass fraction of quantitative data was processed by area normalization method. The composition were determined by mass spectrometry analysis

\section{Results and Discussion}

\section{Infrared Spectrum Analysis}

Fig.1 is infrared spectrogram of high purity NR and control sample. Fig.1 shows that the absorption peaks near on $3280 \mathrm{~cm}^{-1}$ and $1540 \mathrm{~cm}^{-1}$ are stretching vibration absorption peak of N-H group and vibration compound peak of $\mathrm{C}-\mathrm{N}$ group and $\mathrm{N}-\mathrm{H}$ group in amide group, respectively, for the control sample. These groups are caused by protein in NR [11]. However, these groups on $3280 \mathrm{~cm}^{-1}$ and $1540 \mathrm{~cm}^{-1}$ disappear completely for high purity NR.

\section{Py-GC/MS}

Fig. 2 is the total ion figure of high purity NR and the control sample pyrolysis at $550^{\circ}$ C.Fig. 3 is Pyrolysis chromatogram of high purity NR and the control sample. From Fig. 2 and Fig.3, the pyrolysis products and the mass fraction of pyrolysis products of high purity NR and the control sample are obtained according to NIST08.L mass spectrometry library of computer. The results are showed in Table1. 


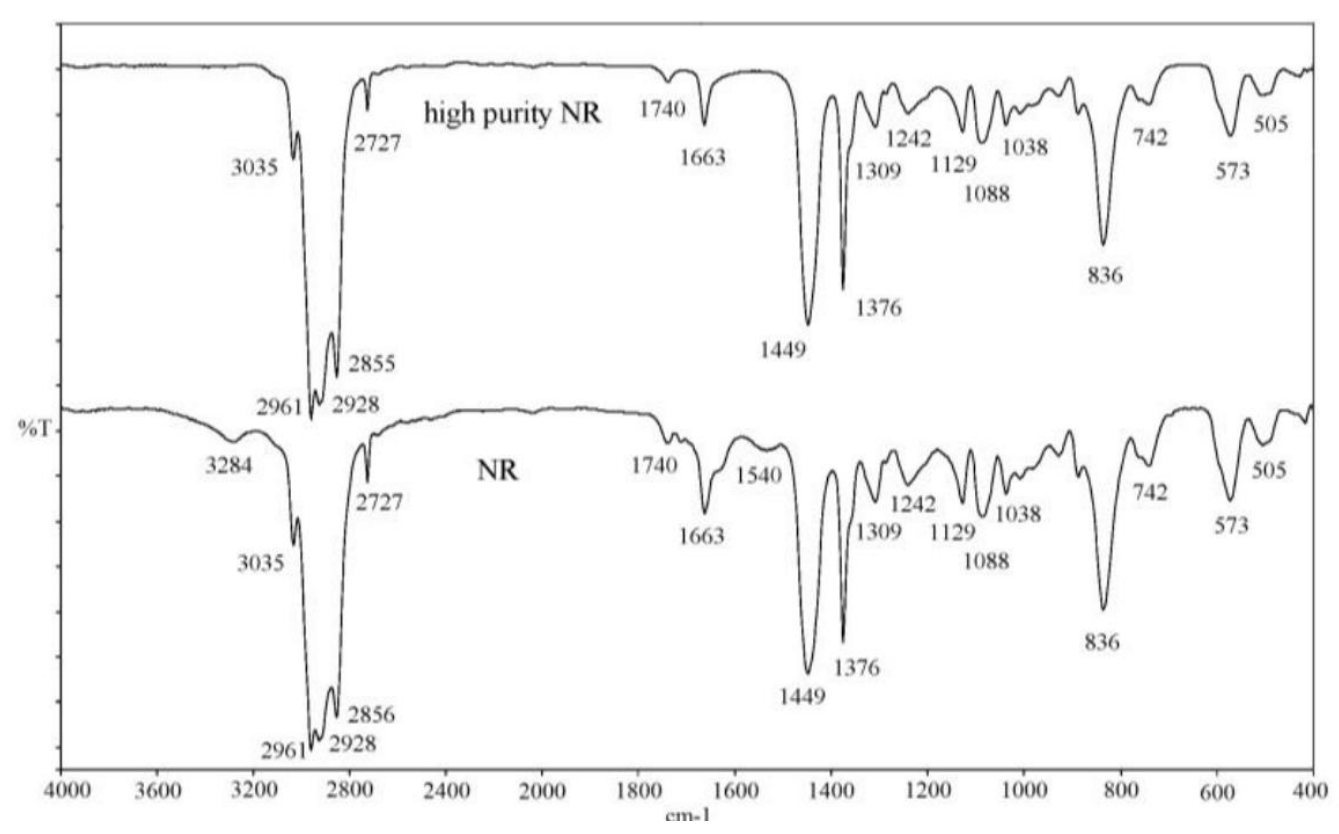

Fig.1 Infrared spectrogram of high purity natural rubber and control sample
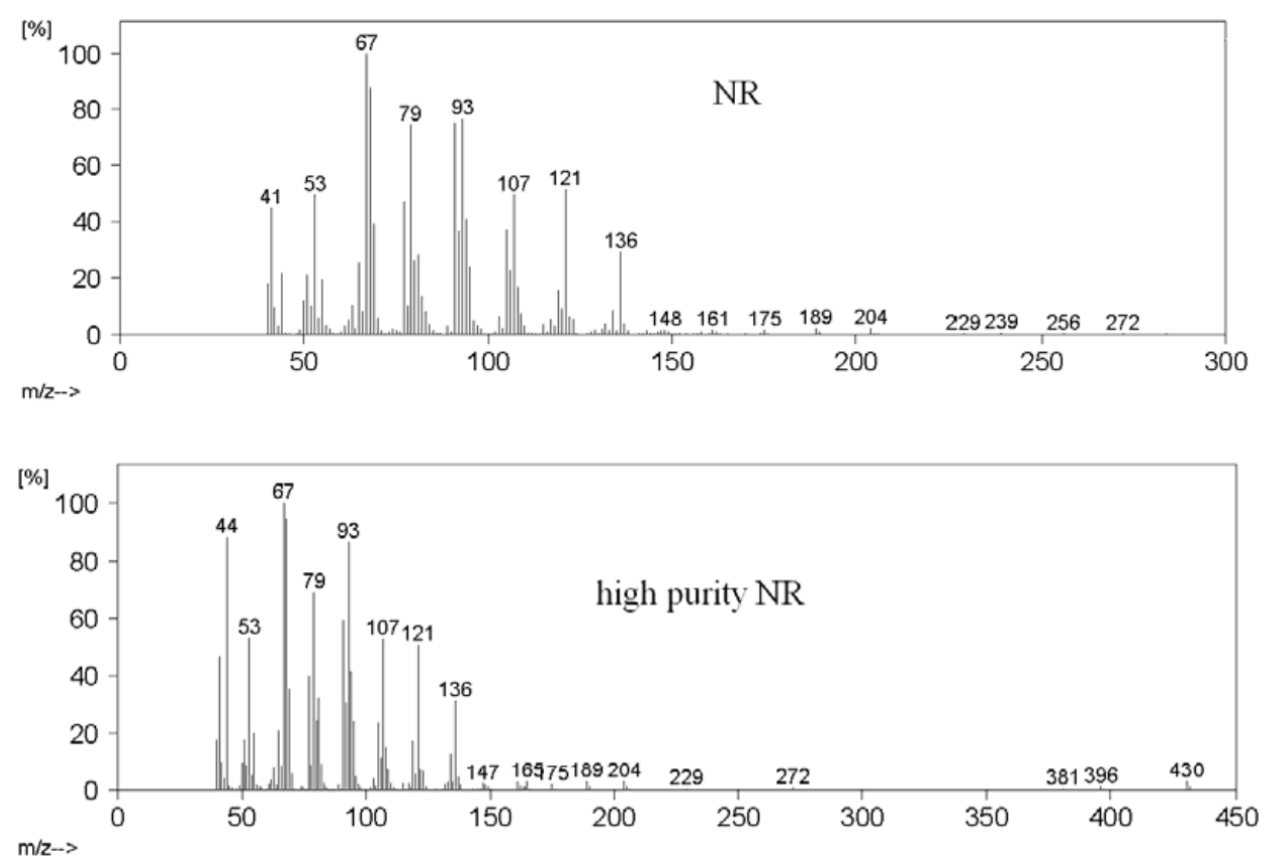

Fig.2 Total ion figure of high purity NR and the control sample pyrolysis at $550^{\circ} \mathrm{C}$

It is known from Table 1 that there are 11 types of pyrolysis products in high purity NR. One of these pyrolysis products is alkyne and others are olefins. The highest levels of three pyrolysis products, in turn, are Limonene, 4-ethenyl-1,4-dimethylCyclohexene and 1,3-Pentadiene.There are 15 types of pyrolysis products in the control sample. Among them, 10 types of pyrolysis products are olefins, 2 types are aromatics, and other three types are alkyne, alkane and condensed aromatic hydrocarbons, respectively. The highest levels of three pyrolysis products, in turn, are limonene, 1, 5, 5-trimethyl-6-methylene-cyclohexene and 1, 3-pentadiene. There appear 2-methyl-1, 3-Butadiene,3-Heptadecen-5-yne, 2,4,6- Trimethyl-1,3,6heptatriene-(3R-trans) Cyclohexene, 4-methyl-1-(1-methylethenyl)-Cyclohexene, $1,3,8-\beta$-Menthatriene, $\beta$-Humulene in pyrolysis products of high purity natural rubber, but above 6 types of compositions do not appear in pyrolysis products of the control 
sample. 1,4-Cyclohexadiene, 2-methyl -1,5-Hexadien-3-yne, 1,3-dimethyl-Benzene, cis-2,6-Dimethyl-2,6-octadiene, 8-methylene -Bicyclo[5.1.0]octane, 1,5,5- Trimethyl -6-methylene-cyclohexene, 3-methyl-6-(1-methylethenyl)- (3R-trans)- yclohexene, 1-methyl-4-(1-methylethenyl)-Benzen, 3-ethenyl-1,2 -dimethyl-1,4- Cyclohexadiene appearing in pyrolysis products of the control sample do not appear in pyrolysis products of high purity natural rubber. There are 5 types of compositions, including 1 , 3-Pentadiene, 1-methyl-1, 4- Cyclohexadiene, 4-ethenyl-1, 4-dimethyl-Cyclohexene, Limonene and 1-ethenyl-1-methyl-2- (1-methylethenyl)- 4-(1-methylethylidene)Cyclohexane appear not only in pyrolysis products of high purity natural rubber but also in pyrolysis products of the control sample. Above 5 types of pyrolysis products are all olefins, and are $73.15 \%$ of the mass fraction of total pyrolysis productions in high purity natural rubber, $49.04 \%$ of the mass fraction total pyrolysis productions in the control sample. It is indicated that the 5 types of pyrolysis products are predominance in all pyrolysis products of high purity NR and the control sample.
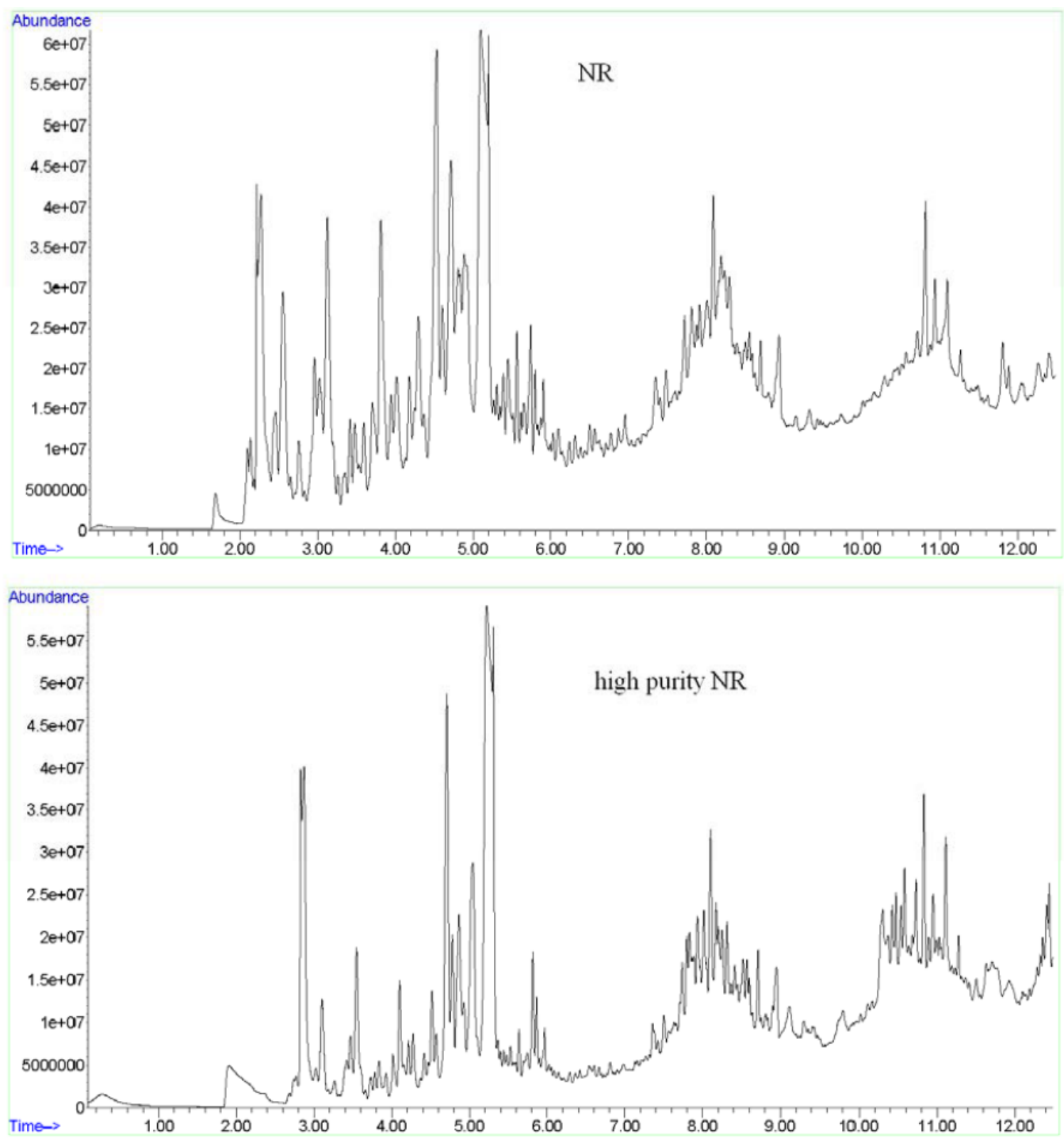

Fig.3 Pyrolysis chromatogram of high purity NR and the control sample 
Table 1 Structures and components of fragment ions corresponding each peak in chromatogram of high purity NR and the control sample

\begin{tabular}{|c|c|c|c|c|c|}
\hline \multirow{2}{*}{$\begin{array}{l}\text { Serial } \\
\text { number }\end{array}$} & \multirow[b]{2}{*}{ Compound } & \multicolumn{2}{|c|}{ Control } & \multicolumn{2}{|c|}{ High purity NR } \\
\hline & & $\begin{array}{l}\text { Respons } \\
\text { time /min }\end{array}$ & $\begin{array}{c}\text { Relative } \\
\text { amount } / \% \\
\end{array}$ & $\begin{array}{l}\text { Response } \\
\text { time /min }\end{array}$ & $\begin{array}{c}\text { Relative } \\
\text { amount } / \%\end{array}$ \\
\hline 1 & 2-methyl-1,3-Butadiene & & & 2.833 & 4.82 \\
\hline 2 & 1,3-Pentadiene & $\begin{array}{l}2.221- \\
2.273\end{array}$ & 11.25 & 2.874 & 11.12 \\
\hline 3 & 1,4-Cyclohexadiene & 2.553 & 5.45 & & \\
\hline 4 & 1-methyl-1,4-Cyclohexadiene & 2.967 & 3.08 & 3.550 & 4.94 \\
\hline 5 & 2-methyl-1,5-Hexadien-3-yne & 3.124 & 6.96 & & \\
\hline 6 & 1,3-dimethyl-Benzene & 3.818 & 5.90 & & \\
\hline 7 & cis-2,6-Dimethyl-2,6-octadiene & 4.302 & 4.27 & & \\
\hline 8 & $\begin{array}{l}\text { 4-ethenyl-1,4-dimethyl-Cyclohexe } \\
\text { ne }\end{array}$ & 4.535 & 11.11 & 4.710 & 11.69 \\
\hline 9 & 8-methylene-Bicyclo[5.1.0]octane & 4.605 & 3.04 & & \\
\hline 10 & $\begin{array}{l}\text { 1,5,5-Trimethyl-6-methylene- } \\
\text { cyclohexene }\end{array}$ & $\begin{array}{l}4.716- \\
4.809\end{array}$ & 13.89 & & \\
\hline 11 & 3-Heptadecen-5-yne & & & 4.780 & 3.53 \\
\hline 12 & 2,4,6-Trimethyl-1,3,6-heptatriene & & & 4.867 & 5.93 \\
\hline 13 & $\begin{array}{l}\text { 3-methyl-6-(1-methylethenyl)- } \\
\text { (3R-trans)-Cyclohexene }\end{array}$ & 4.890 & 7.20 & & \\
\hline 14 & $\begin{array}{l}\text { 4-methyl-1-(1-methylethenyl)- } \\
\text { Cyclohexene }\end{array}$ & & & 5.042 & 9.43 \\
\hline 15 & Limonene & $\begin{array}{l}5.100- \\
5.199\end{array}$ & 21.83 & $\begin{array}{l}5.223- \\
5.304\end{array}$ & 36.17 \\
\hline 16 & $\begin{array}{c}\text { 1-methyl-4-(1-methylethenyl)-Benz } \\
\text { ene }\end{array}$ & 5.561 & 1.26 & & \\
\hline 17 & $\begin{array}{l}\text { 3-ethenyl-1,2-dimethyl-1,4- } \\
\text { Cyclohexadiene }\end{array}$ & 5.741 & 1.64 & & \\
\hline 18 & 1,3,8-p-Menthatriene & & & 5.817 & 1.81 \\
\hline 19 & $\begin{array}{c}\text { 4a,8-dimethyl-2-(1-methylethenyl } \\
\text { )- } \\
\text { Naphthalene }\end{array}$ & 8.090 & 1.34 & & \\
\hline 20 & $\beta$-Humulene & & & $\begin{array}{l}8.108- \\
11.116\end{array}$ & 6.15 \\
\hline 21 & $\begin{array}{c}\text { 1-ethenyl-1-methyl-2-(1-methylethen } \\
\text { yl)- } \\
\text { 4-(1-methylethylidene)-Cyclohexan } \\
\text { e }\end{array}$ & 10.818 & 1.77 & 10.836 & 4.41 \\
\hline
\end{tabular}

\section{Conclusions}

The molecular structure of high purity NR is simpler than that of the control sample, and the pyrolysis productions of high purity NR at $550{ }^{\circ} \mathrm{C}$ are less than that of the control sample. There are 11 types of pyrolysis productions in high purity NR. Limonene, 4-ethenyl-1,4-dimethyl-Cyclohexene, 1,3-Pentadiene are main productions that is $58.98 \%$ of the mass fraction of total pyrolysis productions in high purity NR. 


\section{Acknowledgement}

This research was financially supported by the provincial science and technology planning project of Guangdong (No.2015A020209012)

\section{References}

[1] R.F.A. Altman. Rubber Chemistry and Technology, 1947,Vol.20:1133-1139

[2] E.C.Gregg, J.H.Macey,.Rubber Chemistry and Technology, 1973,Vol.46(1):47-66

[3] A.B.Othman, G.A.W.Murray, A.W.Birley,. Journal of Natural Rubber Research. 1996,Vol.11(3):183-199

[4] S.Tuampoemsab, J.Sakdapipanich, Bangkok,. Kautschuk Gummi Kunststoffe, 2007, 678-683

[5] Kanjanee Nawamawat, Jitladda T. Sakdapipanich, Chee C. Ho,. Macromol. Symp. 2010, 288, 95-103

[6] Zhao Qinxiu, Liu Jianmin, Liu Zutang,. Chinese Journal of Thopical Crops, 1981, Vol.2(2):100-105

[7] M.Morimoto. Effect of Non-rubber Ingredients in Natural Rubber on Ageing Properties. International Rubber Conference 1985. Kuala Lunmpur.pp46-56

[8] Zhe Zhixin, Da Guzhao,. High resolution pyrolysis GC theory and polymer pyrolysis spectrum atas(M). Jin Xi-gao, Luo Yuan -fang translation. Beijing, China Science and Technology Press, 1991,192-193

[9] Zhong Shan, Feng Zigang,. Journal of Instrumental Analysis. 1996, 15, 23-27

[10] Yue Liang, Yong Y. Luo, Wei Jing, Ke Chen, Peng F. Zhao, Pu W. Li, Bei L. Zhang,. Journal of Analytical and Applied Pyrolysis 123 (2017) 118-125

[11]Lu Feijie, Mei Tongxiang, Li Peisen,. Chinese Journal of Thopical Crops, 1987, Vol.8 (2):35-42 